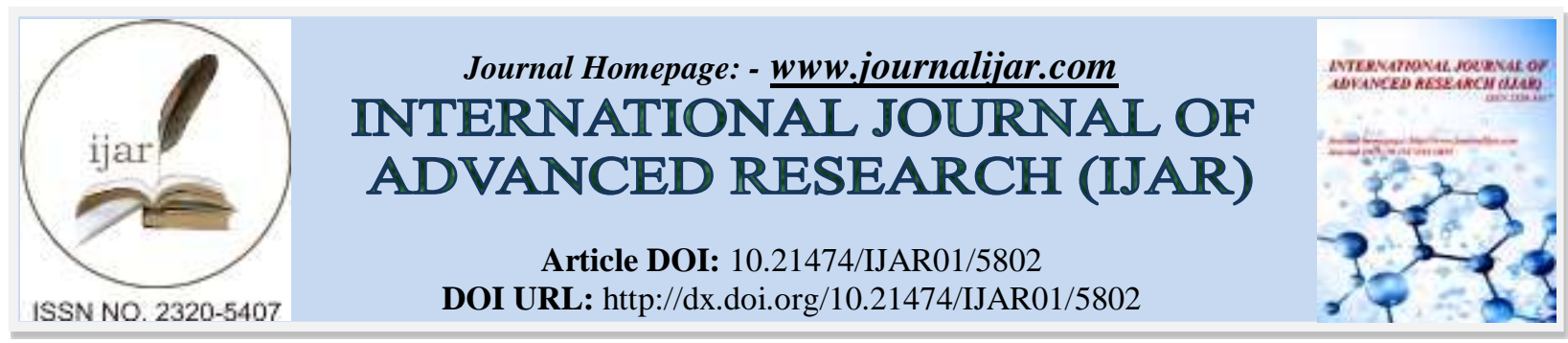

RESEARCH ARTICLE

\title{
A CONCEPTUAL STUDY ON CUSTOMER DELIGHT IN BANKS.
}

\author{
Mrs. R. mathangi ${ }^{1}$, Dr. O. T. V. Latasri ${ }^{2}$ and Dr. L. J. Chaarlas ${ }^{3}$. \\ 1. Research Scholar Commerce (F.T),Shrimathi Indira Gandhi College, Trichy. \\ 2. Assistant Professor, PG and Research Dept. of Commerce, Shrimathi Indira Gandhi College, Trichy. \\ 3. Associate Professor - Head, Department of Commerce, St. Joseph's College, Trichy.
}

\section{Manuscript Info}

Manuscript History

Received: 08 September 2017

Final Accepted: 10 October 2017

Published: November 2017

Key words:-

Customer Delight, Issues, Expectation levels.

\begin{abstract}
In this century, services occupy a significant role in everyone's life. In India banking sector is one of the prime service sectors. The new developments in banking sector have opened up avenues in customer service. For the banks to maintain their position, they should have their customer base intact and develop for which delighting the customer is more important. This paper has made an attempt to highlight the issues both faced by the banking customers as well as the banks in providing satisfied customer service. Also this paper deals with the customer expectation and how the banks by adopting new technology and innovative solutions could delight the customers and be on pace in the growth path. In this paper works from different perspectives including disconfirmation theory, the needs literature and the emotions literature and customer studies have been discussed.
\end{abstract}

Copy Right, IJAR, 2017,. All rights reserved.

\section{Introduction:-}

In the set of service generating industries, the banking services occupy a significant role. It has emerged as an industry. In India the public as well as the private sector banks manage and control the banking services. Today, the banking sector markets a number of services. The boardrooms need a new vision. (1) There are number of services likely to be productive if the policies and strategies are innovated. The banking services waiting for a major change. At this juncture the banking sector needs a sound policy to make possible the optimum utilization of the potentials and to make the development process proactive vis-à-vis productive with the increasing level of customer expectations. To be more specific, it is essential that the banks has to innovate strategies and promote technology driven, user friendly services to increase the market share to project a positive image. It is against this back ground this study made an attempt and identified the concepts of customer delight in banking services.

\section{Objectives of the study:-}

1. To study the importance of customer delight

2. To examine the various issues and concerns in the banking industry.

3. To know the advantages and challenges of banking industry in delighting customers in the emerging scenario.

Need:-

The growing challenges and realities of the industry mainly arising from adoption of technology, addition of new customers in the formal banking structure due to financial inclusion and emergence of new entities like payment 
banks and small finance banks. The banks have to capitalize the situation without any friction/overlap on elimination of customer grievance. (4)

\section{Customer:-}

In sales, commerce and economics, a customer (sometimes known as a client, buyer, or purchaser) is the recipient of a good, service, product or an idea - obtained from a seller, vendor, or supplier via a financial transaction or exchange for money or some other valuable consideration. (3)

The four basic emotions of customers are

1. Glad - Happy, Cheerful, Pleased.

2. Sad - Upset, Dissatisfied, Unhappy

3. Mad - Furious, Resentful, Aggravated

4. Scared - Fearful, Frightened, Nervous

\section{Customer Service:-}

With services, an organization could add to customer's delight. It provides enhanced customer care, services and customer information management across organization to improve customer satisfaction, Customer Delight and loyalty. With an end to end customer care and service solution, organisations can achieve a full 360 degree view of their customer. This translates into better response to customer's needs, an ability to extend pro-active customer management programs as well as having the information at their disposal to understand the customer better. Service applications also track all product defect information, which enables organisations to proactively manage customer issues, so that they are well informed and can also accurately inform customers. The built-in self-learning knowledge base enables companies to leverage employee knowledge and achieve skill transfer, increasing employee retention and reducing customers to churn. Additionally, service applications enables the organisation's customers to communicate with the company through many different venues, webs, call centres and directly with field representatives offering customers flexibility in interacting with the company. This integrated customer contact capability ensures that the customers receive consistent service and information, thereby reducing his need to turn to one of the competitors for new products or services.(2)

\section{Customer Delight:-}

Customer Delight means exceeding customer's expectations. Customer Delight is doing what they haven't even imagined and what will cause them to say "wow". The job is to surprise them. Every interaction with the customer has an opportunity to create delight. Customer expectations are typically not very high. The challenge is to consistently maintain the delight factor. Customer delight must be a way of life for everyone in the firm or organization. The firm or entity know what they can do and not. (10)

According to Rust and Oliver Customer Delight is a deep positive emotional state resulting from exceeding the consumer's expectation positively to a surprising degree. Usually managers define delight pragmatically as "beyond satisfaction". Researchers tend to define delight in terms of "pleasant surprise". The aforesaid dimensions are obvious. (13)

It is against this background, that delight have a sound theoretical foundation and integrating works from different perspectives including disconfirmation theory, the needs literature, the emotions literature and consumer studies.

\section{Focus on customer delight:-}

The new age customers are very different. Their expectation has increased and they are more knowledgeable. They are aware of multiple options to satisfy their needs. They easily switch over to newer brands for better value for their money. Both in the domestic and international market competitors are increasing offering high value based innovative products and process. Although achieving customer satisfaction has long been identified as the heart of the entire marketing concept, most companies pay greater attention to their market share than to their customer's satisfaction. Although meeting customer expectation can satisfy customers, the emotional response, such as an element of surprise, can delight the customers. Even satisfied customers can indulge in brand switching. Thus, not just satisfaction, but the emotional response to satisfaction is what customer delight is all about. All companies need to monitor and improve their level of satisfaction, as satisfied customers truly constitute the company's relationship capital. Hence, it is important to note that customer satisfaction is a necessary but not sufficient goal. Customer satisfaction only remotely predicts customer retention in highly competitive markets because companies regularly 
lose some percentage of their satisfied customers. Thus, companies should aim to delight the customers, not simply to satisfy them.

Customers who experience delight in dealing with a business are more likely to return to the business and also more likely to recommend the business to those they know. For that reason many business are focussing their attention on how they can generate delight in their customers. It is not a new concept. With overwhelming choice, product and price information readily available, customer delight is now being reintroduced. The sustainable strategy for business success and growth strategies for marketing campaigns, pricing, acquisitions, product innovations might have a short term effect. However, if these do not result in customer delight growth will not last.

The point to note here is that customer delight does not necessarily mean to raise the expectations of the customers to a never ending level. A close relationship does exist between customer loyalty and high levels of customer satisfaction become customer delight, customer retention and loyalty increase. A delighted customer (as compared to a merely satisfied customer) is more likely to remain loyal in spite of attractive competitive offerings and a small negative experience will be covered up by an extremely positive one previously. (8)

\section{Advantages of delighting customers:-}

The following are the advantages of delighting a customer: If the organization or firm care about each and every customer then

1. $96 \%$ of unhappy customers disappear.

2. $54 \%-70 \%$ of complaints will return if their complaints are resolved.

3. Costs 5 times to find new customers than it does to retain present ones.

4. Firms with better services charge $9 \%$ more and grow by $6 \%$ a year. (3)

\section{Areas of concerns:-}

Planning and creating delighted customers: All service organizations face choices concerning the types of services to offer and how to deliver them to customers. Delighting a service product is a complex task that requires understanding of how the core and supplementary services should be combined, sequenced, delivered and scheduled to create a value proposition that meets the customers of target segments. Generally a service product comprises all the elements of the service performance both physical and intangible that create value for customers. It has to continue to reinvent its supplementary services surrounding its core products.(10)

\section{Issues from the customer point of view:-}

1. The narration in the passbooks/bank statements at present is quite cryptic and generally inscrutable.

2. Difficulties faced by pensioners in receiving updated pension, issuance of life certificates, verification of signature, need for periodic KYC etc. Several grievances have also been received from nominees of deceased customers while seeking settlement of death claims.

3. Documents to serve as an address proof for KYC compliance continues to remain a major irritant even while the customers are permitted to submit a simple declaration about the current address which may be different from the address proof which was originally submitted to banks.

4. Similarly the customers are also allowed to open a small account in the banks even without proof of identity and address by submitting a recent photograph and signature.

5. While banks have been granted autonomy in fixing minimum average balance or in charging for premium services, it should not be used as an excuse to deny service or to drive away common man.(4)

\section{Challenges in the banking sector:-}

1. Several new small finance banks and payment banks started their operations in the recent past. A significant chunk of these banks would comprise of first-time bank customers belonging to rural and semi-urban population. It is essential that these people are made adequately aware about the need for exercising due prudence while transacting else they can fall prey to fraudsters.

2. The safety of cheques put in the cheque drop boxes as also that of cheque leaves enabling printing of false cheque leaves is a matter of concern for Reserve Bank of India.

3. Customer service to senior citizens is an area of major concern for the RBI.

4. The banks also need to be prepared for following impending regulatory changes as well as enhance their focus on some of the supervisory concerns relating to customer complaints that have been observed by RBI. These are extremely important from the view point of customers. (4) 


\section{Features of delighting customers:-}

Rust and Oliver (2000) conclude that features that can delight customers are unexpected or surprisingly pleasant or add utility to the service or product beyond their expectations. Some new services or products features can serve this role of surprising and delighting customers in certain contexts.(13)

Features on delighting customers includes

1. Attitudes of service champions (3)

1. Take responsibility, put every commitment in writing.

2. Keep a keen or eager desire to serve others.

3. Ability to convey trust, confidence, competence - assuring services.

2. Frontline service provider's skills (3)

1. The staff should represent the organization. Every contact offers a new opportunity for improving the value or quality.

2. Handle emotional situation well.

3. Provide positive strokes where appropriate.

4. Undivided attention to the customers.

5. Be natural, not phony or mechanical.

6. Be positive, energetic, helpful and cordial.

7. Be your customer's agent.

\section{Theory:-}

Satisfaction and dissatisfaction are most studied consumer emotions in the marketing literature. The past two decades have seen increasing interest in emotional states, particularly along the satisfaction, dissatisfaction continuum such as consumer delight and rage.

Delight requires out of the ordinary service or product performance and is more memorable than satisfaction. Moreover delight is used to make separate effects. Existing research on satisfaction cannot be applied to delight.

Three major thresholds along the continuum of satisfaction are the zone of pain, the zone of mere satisfaction, the zone of delight. Moving consumers from the zone of mere satisfaction to the zone of delight may result in significantly better outcomes such as increased retention and sales, positive word of mouth (WOM) and share of wallet.

\section{Disconfirmation theory:-}

Oliver (1981) defines disconfirmation as essentially a mental comparison of an actual state of nature with its anticipated probability. Oliver suggests that when the expectation is exceeded greatly to a surprising degree, consumers would not have expected the product / service to be so good, giving rise to customer delight.(14), (7). Arnold et. al (2005) find that consumers in the retail content are delighted by unanticipated acquisitions and bargains. In the situation of negative disconfirmation high probability desirable events do not occur, while low probability undesirable events occur, no matter whether the consumer's expectations are high or low, a negative disconfirmation state is likely lead to anger. When the negative disconfirmation is combined with a feeling of surprise, the emotion of consumer outrage emerges. (15)

\section{Outcome:-}

Delighted customers display more loyalty, greater likelihood to engage in Word Of Mouth and higher purchase intensions.

\section{The needs literature:-}

According to Schneider and Bowen (1999) propose that consumer delight originate from basic customer needs such as justice and esteem. Meeting consumer's needs offers researchers and managers an opportunity to delve more deeply into their emotional states.(5) Particularly for outrage, fundamental human needs become more significant when the needs are deprived, which can drive consumers to respond with extreme negative emotions and retaliation behaviours. (7). 
Need for justice is the need to be treated fairly, and is often regarded as central to relationships within society and between individuals (Lerner 1980). Berry (1995) notes that the service promise includes the implicit promise of fair play. The needs for a fair service experience in consumers' justice needs given that good service experiences require both justice and fair treatment. Need for esteem, the need to maintain and enhance one's self image is another important basic need. Since consumers are first humans and then only consumers the feelings respected will make consumers delighted.(7)

Based on the disconfirmation theory and the needs literature the consideration of disconfirmation as the cognitive dimension of consumer delight and outrage with justice expectations and esteem expectations are as two separate components. In this sense, when expectations are negatively disconfirmed to a high degree, consumers will feel outraged. When the expectations are slightly disconfirmed they feel merely dissatisfied. Conversely when the expectations are positively confirmed, consumers feel merely satisfied; when the expectations are positively confirmed to high degree they will feel delighted. (7)

\section{The emotions literature:-}

In addition to the disconfirmation dimension, which is cognitive in nature, consumer delight/outrage also has an affective dimension reflecting the emotional responses that arise from disconfirmation. Plutchik (1980) identifies eight basic emotions - Joy, acceptance, fear, surprise, sadness, disgust, anger and anticipation. In this scheme, delight is a "secondary dyad" or a mixture of joy and surprise. Rusell (1980) classifies "valence" and "activation" as the two basic dimensions of emotion. Valence means positive or negative state and Activation means making active or affective.(6)

\section{Building Delight:-}

Successful marketing companies look like the Fig.1. Customers stand at the top. Next in importance is frontline people who meet, serve and satisfy the customers, under them are the middle managers whose job is to hire and support the frontline people. To indicate that managers at all levels must be personally engaged in knowing, meeting and serving customers. customer has been added along the sides of the figure. Companies have been founded on the customer-on-top business model and customer advocacy have been the strategy and competitive advantage all along. Customers expect companies to listen and respond to them. With the rise of digital technology, the highly informed customers expect companies to do, more than just to connect with them, satisfy them and even more than delight them. (16)

Fig(1):- Modern customer-oriented organisation chart.

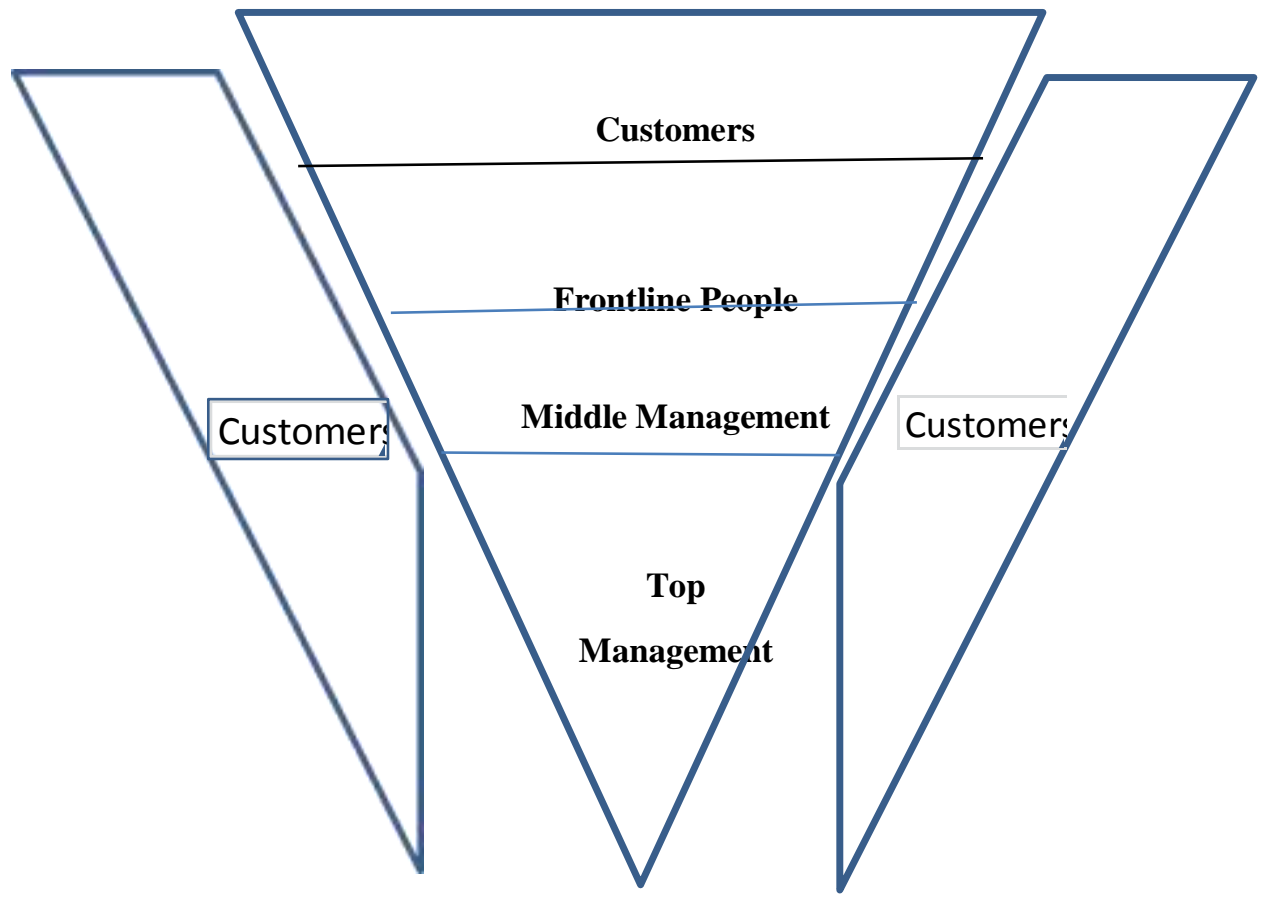




\section{Suggestion and Conclusion:-}

RBI has already advised the small finance banks and payment banks to put in place a high powered customer grievances cell to handle customer complaints and are also to be covered under RBI's banking ombudsman scheme as part of their licensing condition .RBI is in the process of reiterating its guidelines to banks to provide essential minimum relevant details in respect of various transactions in the passbook/statement.

Successful marketers are those who carefully cultivate customer delight and by which they can supersede the competitors.

\section{References:-}

1. Jha .S.M. (2017) Services Marketing. Himalaya Publishing Home. PP 23-24, 143-185

2. H. Peeru Mohamed and A. Sagadevan (2012). Customer Relationship Management A Step-by-Step Approach Vikas Publishing House Pvt. Ltd.PP 84

3. Onkar P. Dhongade MB 12010 Concept of Customer delight - Service Quality Concepts. Web Sources.

4. S.S.Mundra, Deputy Governor, RBI. (2017). Article Customer Service in Banks - Time to Raise the Bar. From RBI Report. Annual Conference of Principal Code of Compliance officers organized by the Banking Codes and Standards Board of India in Mumbai.

5. Schinder.B and Bowen.D.E. (1999). Understanding Customer Delight and Outrage. Sloan Management Review. Vol 41. No.1. PP 35-45

6. PlutChik. R. (1980) Emotion. A Psycho evolutionery Synthesis, Harper \& Row. Newyork.

7. Maggie Wenjing Lik Hean Tat Keh. (2015). Consumer Delight and Outrage. Scale Development and Validation. Journal of Source Theory and Practice. Vol. 25. Iss. 6. PP680-699

8. Vinnie Jauhari,Kirti dutta.(2010) Services Marketing, Operations and Management. Oxford University Press Pp128\&129.

9. Dr E.J. Sarma, Head. HCM-Global.

10. Ken Banchard Sheldon Bowles. Raving Fans - A Revolutionary Approach to Customer Service.

11. Loree Mc Donald O' Sullivan. 2014. Customer Satisfaction Vs Customer Delight. http://blog.satmetrix.com

12. Gregory Clotti. (2013). www.helpsout.net/blog/customer satisfaction. The Ultimate Guide to Measuring Customer Satisfaction.

13. Rust, R.T and Olivr.R.L.(2000). Should We Delight the Customer?. Journal of the Academy of Marketing Science. Vol 28. N0.1. PP 86-94

14. Oliver, R.L.(1981), Measurement and Evaluation of Satisfaction Processes in Retail Settings. Journal of Retailing. Vol. 57. No.3. Pp 25-43

15. Arnold M.J., Reynolds, K.E., Ponder, N and Lueg, J.E (2005), Customer Delight in a retail contest: investigating delightful and terrible shopping experiences. Journal of Business Research. Vol. 58. No. 8. Pp $1132-1145$

16. Bloomberg via Getty Images. Part I - Understanding Marketing Management - Pp 68. 